[P

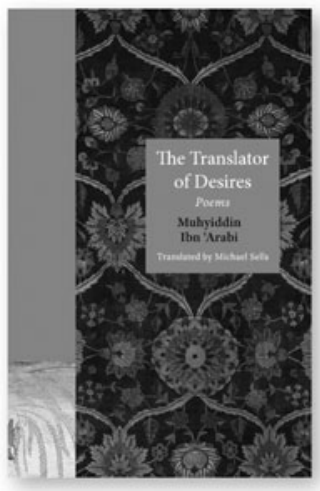

A masterpiece of Arabic love poetry in a new and complete English translation

"Accurate yet not overawed by the Arabic texts, this authoritative translation renders

Ibn 'Arabi's Translator of Desires into a nuanced, flexible, and accessible modern idiom that enables English readers to enjoy the delights of these poetic gems."

-James E. Montgomery,

University of Cambridge

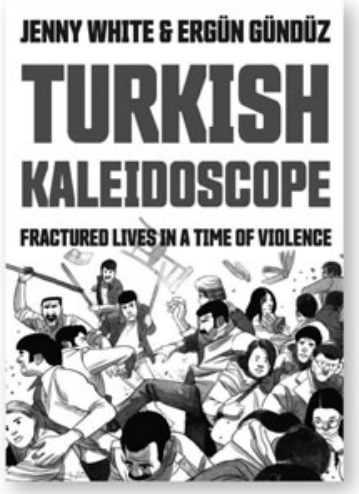

A powerful graphic novel that traces Turkey's descent into political violence in the 1970s through the experiences of four students on opposing sides of the conflict

"Turkish Kaleidoscope is a meticulously researched and beautifully illustrated depiction of a pivotal period in twentieth-century Turkish history. Moving and informative."

-Elif Batuman, author of The Idiot 

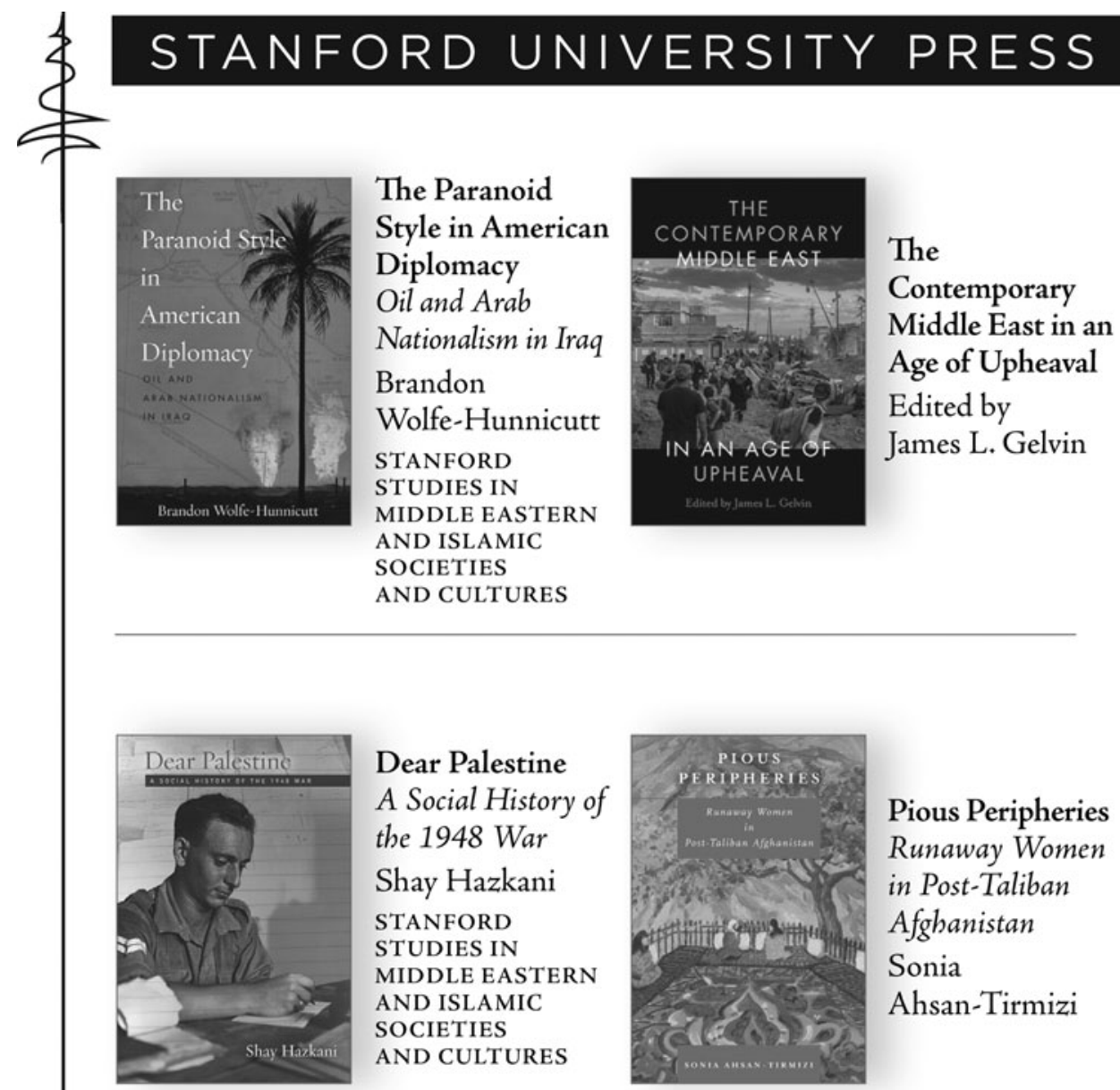

Dear Palestine
A Social History of
the 1948 War
Shay Hazkani
STANFORD
STUDIES IN
MIDDLE EASTERN
AND ISLAMIC
SOCIETIES
AND CULTURES

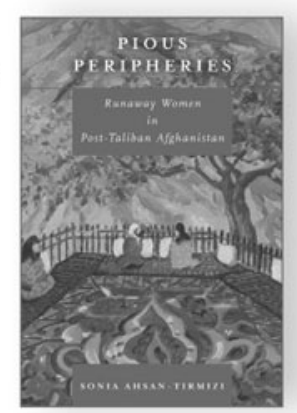

Pious Peripheries Runaway Women in Post-Taliban Afghanistan Sonia Ahsan-Tirmizi

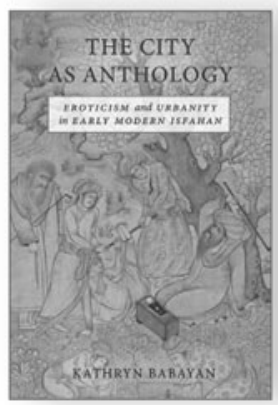

\section{The City} as Anthology Eroticism and Urbanity in Early Modern Isfahan

Kathryn Babayan

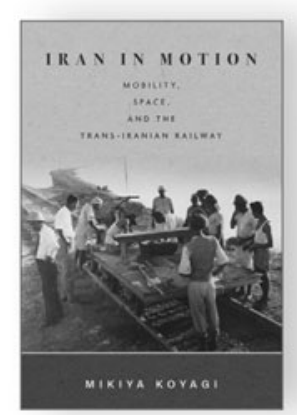

Iran in Motion Mobility, Space, and the TransIranian Railway Mikiya Koyagi 
Wilson Chаско Jасов, For God or Empire: Sayyid Fadl and the Indian Ocean World

(Reviewed by Michael O'Sullivan)

Jennifer L. Derr, The Lived Nile: Environment, Disease, and Material Colonial Economy in Egypt (Reviewed by Elizabeth Williams)

Shana Minkin, Imperial Bodies: Empire and Death in Alexandria, Egypt (Reviewed by Lucia Carminati)

Hugh Beattie, Empire and Tribe in the Afghan Frontier Region: Custom, Conflict and British Strategy in Waziristan until 1947

(Reviewed by Elisabeth Leake)

\section{Identities}

Walter Armbrust, Martyrs \& Tricksters: An Ethnography of the Egyptian Revolution, Princeton Studies in Muslim Politics

(Reviewed by Sherine Hamdy)

Arbella Bet-Shlimon, City of Black Gold: Oil, Ethnicity, and the Making of Modern Kirkuk (Reviewed by Carl Shook)

Menahem Merhavy, National Symbols in Modern Iran: Identity, Ethnicity, and Collective Memory (Reviewed by Assal Rad)

Catherine Z. SAmeh, Axis of Hope: Iranian Women's Rights Activism Across Borders (Reviewed by Niki Akhavan)

ERIC LoB, Iran's Reconstruction Jihad: Rural Development and Regime Consolidation after 1979 (Reviewed by Maryam Alemzadeh)

Eve Spangler, Understanding Israel/Palestine: Race, Nation, and Human Rights in the Conflict (Second Edition) (Reviewed by Matthew DeMaio)

Eyal Clyne, Orientalism, Zionism and Academic Practice: Middle East and Islam Studies in Israeli Universities. (Reviewed by Benjamin E. Norquist) 


\section{CONTENTS}

\section{ARTICLE}

Robert STEele Crowning the "Sun of the Aryans": Mohammad Reza Shah's Coronation and Monarchical Spectacle in Pahlavi Iran

$175-193$

$195-212$

$213-233$

Ali Ahmad Hussein Two Sources for Abu Dhu'ayb al-Hudhali's Famous Elegy

ARIANE SADJED Conversion, Identity, and Memory in Iranian-Jewish Historiography:

The Jews of Mashhad

$235-251$

Aviv DerRI The Construction of "Native" Jews in Late Mandate Palestine: An Ongoing Nahda as a Political Project

$253-271$

PhilipPe PÉTriat The Uneven Age of Speed: Caravans, Technology, and Mobility in the Late Ottoman and Post-Ottoman Middle East

273-290

FOUNDATIONAL TEXT

StUART SchaAR Reflections on North African History: Abdallah Laroui and his History of the Maghrib

\section{ROUNDTABLE}

\section{Ottoman Ego-Documents}

Selim KarahasanoĞLU Ottoman Ego-Documents: State of the Art

$301-308$

İLKer Evrim BinbaŞ Autobiographies and Weak Ties: Sa'in al-Din Turka's Self-Narratives

309-313

A. Tunç ŞEN The Emotional Universe of Insecure Scholars in the Early Modern Ottoman Hierarchy of Learning

R. Aslihan AKsoy Sheridan ～Nostalgia of a Frustrated Ottoman Subject: Reading Osman Agha of Timişoara's Memoirs as Self-Narrative

SEMRA ÇörekÇI The Dream Diary of an Ottoman Governor: Kulakzade Mahmud Pasha's Düşnama

$331-335$

Suraiya FaroQhi Aziz Nesin about Himself and His Parents: Poor People in Istanbul during the Late Ottoman Period

\section{BOOK REVIEWS}

\section{Pre-Modern Studies}

Daniella Talmon-Heller, Sacred Place and Sacred Time in the Medieval Islamic Middle East:

A Historical Perspective

(Reviewed by Harry Munt)

JonATHAN A. C. BRown, Slavery and Islam

(Reviewed by Elizabeth Urban)

\section{Modern History}

ARTHUR AssERAF, Electric News in Colonial Algeria

(Reviewed by Julian Weideman)

348-349

\section{Cambridge Core}

For further information about this journal please go

to the journal website at:

cambridge.org/mes
CAMBRIDGE UNIVERSITY PRESS 